\title{
Current management options for tyrosinemia
}

\author{
Mortada Hassan \\ El-Shabrawi \\ Naglaa Mohamed Kamal \\ Pediatric Hepatology, Faculty \\ of Medicine, Cairo University, \\ Cairo, Egypt
}

This article was published in the following Dove Press journal:

Orphan Drugs: Research and Reviews

27 February 2013

Number of times this article has been viewed
Abstract: Hypertyrosinemia is observed in three inherited disorders of tyrosine metabolism. Hereditary Tyrosinemia Type I (HTT-I), or hepatorenal tyrosinemia, is an autosomal recessive disorder caused by mutation in the fumarylacetoacetate hydrolase $(F A H)$ gene. HTT-I is associated with severe involvement of the liver, kidneys, and central nervous system, and is due to toxic accumulation of metabolites of tyrosine, such as succinylacetone. HTT-I is the inborn error with the highest incidence of progression to hepatocellular carcinoma. Elevated succinylacetone, in dried filter paper blood samples, or in plasma or urine, is pathognomonic and diagnostic for HTT-I and is the most reliable neonatal screening method. Liver transplantation is the definitive management, but the need for this is markedly decreased by the combined dietary and drug management. A diet low in tyrosine and phenylalanine, plus nitisinone (2-[2-nitro-4-trifluoromethylbenzoyl]-1,3-cyclohexanedione) (NCTB) are considered the gold standard management options. Carnitine and 1,25-OH-vitamin D are adjuvant therapy. Strict follow up with succinylacetone level for monitoring of treatment should be done. Abdominal ultrasonography and abdominal computerized tomography scan or magnetic resonance imaging should also be done for surveillance of the possible development of hepatocellular carcinoma.

Keywords: tyrosinemia, management, NTBC, hepatocellular carcinoma

\section{Introduction and background}

Tyrosine is obtained from ingested proteins and is synthesized endogenously in humans from phenylalanine. It is used for protein synthesis and is a precursor of dopamine, norepinephrine, epinephrine, melanin, and thyroxin. Hypertyrosinemia is observed in three inherited disorders of tyrosine metabolism. ${ }^{1}$ Hereditary Tyrosinemia Type I (HTT-I; MIM 276700) is an autosomal recessive disorder caused by homozygous or compound heterozygous mutation in the encoding fumarylacetoacetate hydrolase $(F A H)$ gene, encoding FAH, on chromosome 15q23-q25. ${ }^{2}$ More than 40 mutations have been reported. ${ }^{3-4}$ The first report of a patient with elevated blood tyrosine was by Medes, in $1932 .{ }^{5}$ Patients with a more typical clinical and biochemical picture of tyrosinemia were then described in the late 1950 s. $^{6-9}$ Since then, more than 500 patients have been reported in the literature. ${ }^{10-12}$ While a predominance of patients are of French Canadian or Scandinavian descent, people from other ethnic groups have also been diagnosed. ${ }^{13}$ Hereditary Tyrosinemia Type II (HTT-II) is a rare autosomal recessive disorder caused by deficiency of tyrosine aminotransferase, which acts at the first step in tyrosine catabolism. ${ }^{14}$ Described in 1973, patients are predominately Italian, but other ethnic groups are represented as well. ${ }^{13}$ Hereditary Tyrosinemia Type III
Correspondence: Mortada Hassan El-Shabrawi

Pediatric Hepatology, Cairo University 3 Nablos Street, off Shehab Street, Mohandesseen, Cairo I24I I, Egypt $\mathrm{Tel}+20 \mathrm{I} 23 \mathrm{I} 33705$

$\mathrm{Fax}+20237619012$

Email melshabrawi@medicine.cu.edu.eg
Orphan Drugs: Research and Reviews 2013:3 I-9

(c) 2013 El-Shabrawi and Kamal, publisher and licensee Dove Medical Press Ltd. This is an Open Access

Dovepress

http://dx.doi.org//0.2147/ODRR.S31501 
(HTT-III) is an even rarer disorder caused by deficiency of 4-hydroxyphenylpyruvate dioxygenase (4HPPD). ${ }^{15,16}$ Only a few patients have been described with this disorder. ${ }^{15,16}$ The causal relationship of high levels of tyrosine with the diseased state has been established only in deficiency of tyrosine aminotransferase. ${ }^{1}$ The significance of hypertyrosinemia in the pathogenesis of the other two enzyme deficiencies is unclear. ${ }^{1}$ Figure 1 illustrates the phenylalanine and tyrosine metabolic pathways and the enzymatic defects leading to the different types of hereditary tyrosinemias.

Deficiencies of other enzymes involved in tyrosine degradation cause little or no increase in blood levels of tyrosine. ${ }^{1}$ In addition to the three inherited disorders, transient neonatal hypertyrosinemia, primarily in premature infants (probably caused by immaturity of tyrosine aminotransferase enzyme activity), is a major cause of tyrosine elevation detected on newborn screening. ${ }^{17}$ Acquired hypertyrosinemia may occur in conditions such as severe hepatocellular dysfunction (liver failure), scurvy (vitamin C is the cofactor of 4-HPPD enzyme), and hyperthyroidism. ${ }^{1}$

\section{Diagnosis by both characteristic clinical picture and investigations Clinical picture HTT-I}

HTT-I, also known as hepatorenal tyrosinemia, is the most common of the three known hereditary diseases caused by defective tyrosine metabolism. ${ }^{18}$ In this condition, a moderate elevation of serum tyrosine is associated with severe involvement of the liver, kidneys, and central nervous system. ${ }^{19}$ These findings are thought to arise from the accumulation of toxic metabolites of tyrosine, such as maleylacetoacetate, fumarylacetoacetate, succinyl-acetoacetate, and succinylacetone, which are highly reactive electrophilic toxic compounds and which bind to sulfhydryl groups, often leading to tissue injury. ${ }^{17}$

There are two forms of HTT-I, acute and chronic. The acute form presents in infancy, with severe liver dysfunction manifested by jaundice, hepatosplenomegaly, failure to thrive, anorexia, ascites, coagulopathy, and rickets. The disorder may actually begin in utero, as evidenced by the significantly high levels of $\alpha$-fetoprotein in the cord blood of affected infants and the presence of well-established cirrhosis, with large regenerative nodules, during infancy. The chronic form presents later in childhood with cirrhosis, renal tubular dysfunction, rickets, and hepatocellular carcinoma (HCC). ${ }^{17,20-22}$ The acute hepatic crises occur frequently; usually precipitated by an intercurrent illness

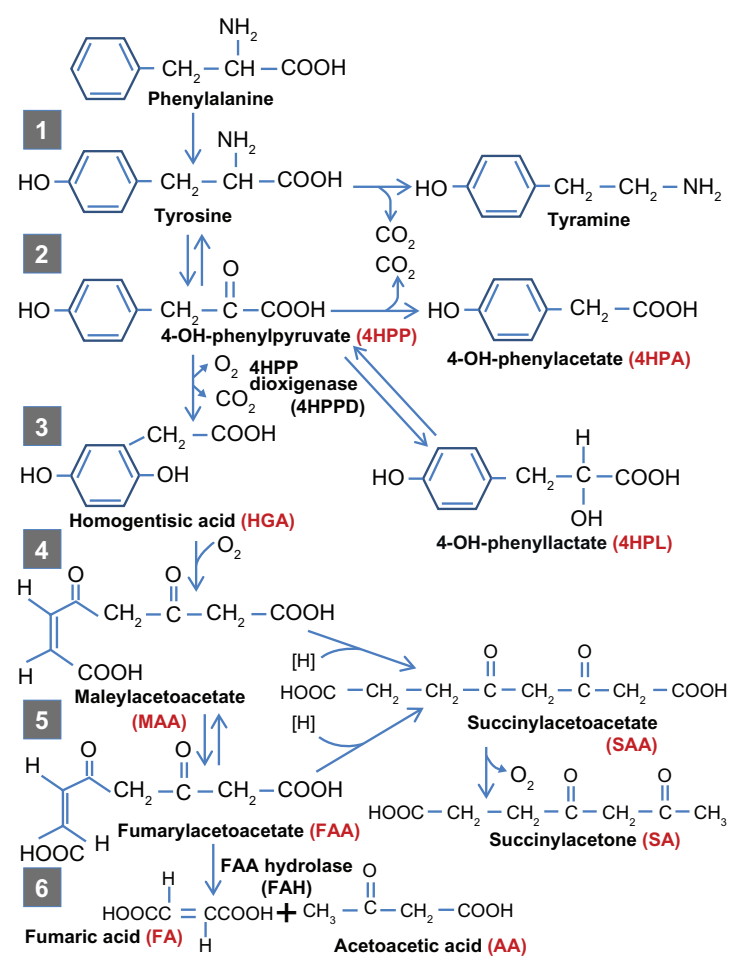

Figure I The phenylalanine and tyrosine metabolic pathways and the enzymatic defects leading to the different types of hereditary tyrosinemias.

Notes: Step 2 is carried by tyrosine aminotransferase. Mutations of this enzyme lead to hereditary tyrosinemia type 2. Step 3 is carried by hydroxyphenylpyruvate oxidase. Mutations of this enzyme result hereditary tyrosinemia type 3 . This enzyme is the target of nitisinone. Step 6 is carried by fumarylacetoacetate hydrolase. Mutations of this enzyme result hereditary tyrosinemia type I with accumulation of the toxic metabolites; fumarylacetoacetate and malelylacetoacetate which in turn convert to the toxic succinyacetoacetate and succinyacetoacetone. Reproduced with permission from Kitagawa T. Hepatorenal tyrosinemia. Proc Jpn Acad Ser B Phys Biol Sci. 2012;88(5):192-200.96

that produces a catabolic state. ${ }^{23}$ An odor resembling boiled cabbage may be present and may be due to increased methionine metabolites. ${ }^{23}$ Hepatorenal tyrosinemia is the inborn error with the highest incidence of progression to HCC, likely due to profound mutagenic effects and influences on the cell cycle by accumulated metabolites. ${ }^{21}$ Weinberg et al, ${ }^{24}$ reported $37 \%$ incidence of $\mathrm{HCC}$ in these patients, but it is now postulated that the incidence is much lower. ${ }^{23}$

Actually, the earlier the presentation, the poorer is the prognosis. Survival, when symptoms develop before two months of age, between two and six months, and after six months, is $38 \%, 74 \%$, and $96 \%$, respectively. ${ }^{22}$ Succinylacetone is a potent inhibitor of aminolevulinic acid (ALA) dehydrase, ${ }^{25-27}$ and therefore, results in increased urinary excretion of 5-ALA. Forty percent of patients have acute neurologic crises resembling those of the acute intermittent porphyrias. ${ }^{28}$ The mechanism of neurologic dysfunction may be the same because patients with tyrosinemia respond to the intravenous administration of hematin. ${ }^{29}$ These crises have two phases: 
(1) an active phase of acute peripheral neuropathy ${ }^{28}$ with severe pain, often in the legs, associated with hypertonia (causing hyperextension of the trunk and neck), vomiting, paralytic ileus, and occasionally, self-induced injuries, ${ }^{23,30}$ (2) a period of recuperation, with marked weakness and paralysis occurring in about $30 \%$ of episodes, which may lead to respiratory failure and death. ${ }^{17,23}$ These crises may last one to seven days. ${ }^{23}$

Renal involvement is manifested as a Fanconi-like syndrome with a normal anion gap metabolic acidosis, hyperphosphaturia, hypophosphatemia, glucosuria, aminoaciduria, ${ }^{1,10,14}$ and vitamin D-resistant rickets. ${ }^{31}$ Nephromegaly ${ }^{10,32}$ and some degree of nephrocalcinosis are often found. ${ }^{23}$ Chronic renal failure may occur in adolescents and young adults. ${ }^{33,34}$

Hypertrophic cardiomyopathy is occasionally seen in these infants. ${ }^{35-37}$ Edwards et $\mathrm{al}^{38}$ described an obstructive cardiomyopathy in two symptomatic cases.

Hyperplasia and hypertrophy of the islets of Langerhans have been reported in a large number of cases, ${ }^{10,39-40}$ and hyperinsulinism has occasionally been documented. ${ }^{41}$

Chronic hypoglycemia has rarely been documented, and most patients have normal blood glucose levels. ${ }^{23}$ Patients with HTT-I do not have mental retardation. ${ }^{14}$

\section{HTT-II (Richner-Hanhart Syndrome or oculocutaneous tyrosinemia)}

This disorder results in accumulation of tyrosine that crystallizes in cells and tissues, leading to palmar and plantar punctate hyperkeratosis, herpetiform corneal ulcers, and mental retardation. ${ }^{42}$ The eye manifestations of excessive tearing, redness, pain, and photophobia may occur before skin lesions. Corneal lesions usually occur during the first few months of life. Skin lesions, which may develop later in life, include painful, nonpruritic hyperkeratotic plaques on the soles, palms (especially thenar and hypothenar areas), and finger tips. ${ }^{43}$ Mental retardation, which occurs in less than $50 \%$ of patients, is usually mild to moderate and may be associated with self-mutilation. ${ }^{42}$ Hepatic and renal functions remain intact. $^{23}$

\section{HTT-III}

Only four cases with this disorder have been reported. ${ }^{1}$ They all have various neurologic findings but no consistent clinical phenotype. ${ }^{42}$ Age at onset has been from one-17 months. ${ }^{1}$

Developmental delay, seizures, intermittent ataxia, and self-destructive behavior have been the main neurologic findings. No liver or renal abnormalities are present. The first affected individual came to medical attention because of mental retardation and ataxia; another was detected on routine screening. ${ }^{44}$

These individuals, like those with HTT-II, have no liver involvement but have skin and/or ocular changes. It remains unclear whether HTT-III is truly associated with cognitive delays or whether the association has resulted from ascertainment bias. ${ }^{45}$

\section{Transient tyrosinemia of the newborn}

In a small number of newborn infants, plasma tyrosine may rise to as high as $60 \mathrm{mg} / \mathrm{dL}$ during the first two weeks of life. ${ }^{1}$ Most affected infants are premature and receiving high-protein diets. The condition resolves spontaneously and is presumed to be due to delayed maturation of 4-HPPD in the liver. ${ }^{14}$ Lethargy, poor feeding, and decreased motor activity occur in some of these infants, but most are asymptomatic and come to medical attention because of a high blood phenylalanine level detected by the screening test for phenylketonuria. ${ }^{23}$

\section{Investigations}

HTT-I

HTT-I is diagnosed from abnormalities found in biochemical investigations, imaging studies, liver biopsy, enzyme assay, genetic testing and mutation analysis, prenatal screening, and neonatal screening, as follows.

\section{Biochemical investigations}

a. Basic investigations

- Complete blood count: normocytic anemia ${ }^{1}$

- Liver function tests: elevation of serum unconjugated and conjugated bilirubin, transaminases, and gamma glutamyl transpeptidase with hyperammonemia and marked compromise in hepatic synthetic functions, with hypoprothrombinemia ${ }^{1,17,46}$

- Kidney function tests: picture of Fanconi Syndrome with hypophosphatemia, hyperphosphaturia, glucosuria, aminoaciduria, metabolic acidosis. ${ }^{1,17,46}$ Blood urea nitrogen and creatinine may be elevated ${ }^{47}$

- Blood biochemistry: hypoglycemia ${ }^{17,46}$

- Bone biochemistry: high alkaline phosphatase (rickets) ${ }^{47}$

b. Specific investigations

- Serum and cord blood $\alpha$-fetoprotein: marked elevation ${ }^{1,17,46}$ 
- Serum amino acids: moderate increase of tyrosine (>300 $\mu \mathrm{mol} / \mathrm{L}$ ), phenylalanine, and other amino acids, especially methionine (secondary inhibition of methionine adenosyltransferase) $)^{1,17,22,46}$

- Urinary amino acids: generalized hyperaminoaciduria $^{46}$

- Urinary delta-ALA: increased ${ }^{1,46}$

- Elevated succinylacetone in blood or urine is pathognomonic and diagnostic. ${ }^{46,48-51}$

\section{Imaging studies}

- Abdominal ultrasonography, computed tomography, or magnetic resonance imaging (MRI) ${ }^{52}$ heterogeneous liver parenchyma, hypoechogenic hepatic micronodules $(<5 \mathrm{~mm})$, and hyper- or hypoechogenic macronodules ( $\geq 5 \mathrm{~mm}$ ). There may be nephromegaly $+/-$ nephrocalcinosis. ${ }^{23,46}$ MRI with contrast can differentiate regenerative nodules from those of HCC, as the former contain functioning hepatocytes, which can uptake the contrast and excrete it in bile, while the latter don't and thus show reduced enhancement. ${ }^{23}$

- X ray of the wrist: for evidence of rickets. ${ }^{47,53}$

\section{Liver biopsy}

- Compatible with chronic hepatitis and nonspecific cirrhosis, ${ }^{1}$ with pseudo acinar formation. ${ }^{17}$

\section{Enzyme assay}

- FAH activity in lymphocytes, ${ }^{54}$ erythrocytes,${ }^{55}$ fibroblasts, and liver biopsy specimens, ${ }^{23}$ the degree of residual enzyme activity dictates the disease severity. ${ }^{13,46}$

\section{Genetic testing and mutation analysis}

- Many mutations in the FAH gene have been described. ${ }^{44}$ The IVS12+5ga allele accounts for about $90 \%$ of mutant FAH alleles in the Saguenay-Lac St-Jean area of Quebec. ${ }^{56,57}$ IVS12+5ga and IVS6-1gt are frequent in patients of diverse ethnic origins. ${ }^{58} \mathrm{In}$ addition, W262X is prevalent in Finns, ${ }^{59,60}$ and Q64H (192GT) in Pakistanis.$^{61} \mathrm{R} 341 \mathrm{~W}$ causes pseudodeficiency. ${ }^{62}$

\section{Prenatal diagnosis}

- Prenatal diagnosis for Type I can be accomplished by detecting succinylacetone in amniotic fluid and finding deficient FAH activity in chorionic villus cells or cultured amniocytes. ${ }^{13,46}$

\section{Neonatal screening}

- Measurement of succinylacetone in a dried blood spot, using tandem mass spectrometry: ${ }^{46,49,50,63-65}$ Screening using blood tyrosine as a marker leads to many false-positive results, in newborns with transient tyrosinemia, in those with other hereditary tyrosinemias, and occasionally in children with hepatic problems other than hepatorenal tyrosinemia, ${ }^{23}$ more importantly, false-negative results may be obtained in children affected with hepatorenal tyrosinemia, ${ }^{44}$ particularly in this era of low neonatal protein intake (breast-feeding, humanized formulas) and early hospital discharge, two factors that reduce the levels of blood tyrosine in predischarge samples. ${ }^{23}$

This condition should be differentiated from other causes of hepatitis and hepatic failure in infants, including galactosemia, hereditary fructose intolerance, neonatal iron storage disease, biliary atresia, and severe neonatal giant-cell hepatitis. $^{1,46}$

\section{HTT-II}

Abnormal laboratory findings include the following: (1) significant isolated hypertyrosinemia, typically $>500 \mu \mathrm{mol} / \mathrm{L}$ and may exceed $1000 \mu \mathrm{mol} / \mathrm{L}$, and tyrosinuria. ${ }^{53}$ (2) Increased excretion of p-hydroxyphenylpyruvate, p-hydroxyphenyllactate, and p-hydroxyphenylacetate, and the presence of small quantities of $\mathrm{N}$-acetyl tyrosine and 4-tyramine on urine organic acid analysis..$^{53}$ In contrast to HTT-I, liver and kidney functions, as well as serum concentrations of other amino acids, are all normal. ${ }^{1}$

Tyrosine aminotransferase activity can be measured in the liver and kidneys. ${ }^{12}$

\section{HTT-III}

The diagnosis is established by moderate increases in plasma levels of tyrosine $(350-700 \mu \mathrm{mol} / \mathrm{L})$, the presence of 4-hydroxyphenylpyruvic acid and its metabolites (4-hydroxyphenyllactic and 4-hydroxyphenylacetic acids) in urine, and low activity of 4-HPPD enzyme in liver biopsy. ${ }^{1,13}$

\section{Transient tyrosinemia of the newborn}

Laboratory findings include marked elevation of plasma tyrosine with a moderate increase in plasma phenylalanine. The presence of marked hypertyrosinemia differentiates this condition from phenylketonuria. As well, 4-hydroxyphenylpyruvic acid and its metabolites (4-hydroxyphenyllactic and 4-hydroxyphenylacetic acids) are also present in the urine. ${ }^{1}$ 


\section{Treatment}

Because the diagnosis and therapy of tyrosinemia is complex, the pediatrician is advised to manage the patient in close collaboration with a consulting pediatric metabolic disease specialist and a dietitian. It is recommended that parents move with a letter of treatment guidelines from the patient's physician. ${ }^{13}$

\section{HTT-I}

Previously, almost all patients died in infancy and early childhood. In the 50 years since the description of tyrosinemia, ${ }^{7}$ the course of the disease has been improved successively by the introduction of diet therapy, neonatal screening, and hepatic transplantation. The advent of liver and kidney transplantation as a definitive treatment revolutionized the outcome. ${ }^{11,12,66-68}$ Recently, the availability of nitisinone (NTCB), a peroral inhibitor of the tyrosine catabolic pathway (at an early step preceding the metabolic defect), ${ }^{69,70}$ has provided hope for a nonsurgical solution.

Management of HTT-I includes: (a) adequate supportive management for hepatic and neurologic crises and renal effects (which now rarely occur with combined dietary and NTCB management); 1,53 (b) drug management; (c) dietary management; (d) liver transplantation; (e) gene therapy and hepatocyte transplantation; (f) genetic counseling; and (g) cognitive evaluation.

\section{Drug management}

Primary drug management

NTCB, 2-[2-nitro-4-trifluoromethylbenzoyl]-1,3-cyclohexanedione (Orfadin ${ }^{\circledR}$, Swedish Orphan Biovitrum, Stockholm, Sweden), is the mainstay of treatment of HTT- I. ${ }^{71}$

NTBC is a triketone with herbicidal activity that has been shown to have a novel mode of action - by inhibiting the enzyme 4-HPPD in plants. ${ }^{71}$ Inhibition of 4-HPPD, the second step in the tyrosine degradation pathway, prevents the formation of tyrosine toxic metabolites. ${ }^{19}$ In 1991, Lindstedt et $\mathrm{al}^{70}$ discovered the potential of NTBC in the treatment of HTT-I, and they successfully used it in five patients. This report led to widespread clinical trials that largely reproduced the original experience. ${ }^{17}$ Its efficacy in the treatment of HTT-I has well been recognized, and it was approved by the United States Food and Drug Administration (FDA) in April 2002. ${ }^{72}$ NTBC has radically improved the course of the disease, preventing acute hepatic and neurologic crises. It has improved the survival and quality of life of patients. ${ }^{18,73-78}$
The recommended starting dose of NTBC is $1 \mathrm{mg} / \mathrm{kg} /$ day, divided into two daily doses (Orfadin European Public Assessment Report [EPAR] product information, Orfadin package insert). ${ }^{19,79}$ Recently, it has been reported that doses lower than $1 \mathrm{mg} / \mathrm{kg} /$ day have also been effective in the treatment of HTT-I. ${ }^{80,81}$ Based on the fact that the half-life of NTBC is known to be 54 hours, ${ }^{82}$ Schlune et al, ${ }^{19}$ used a single daily dose regimen in their patients, and they suggested that a single daily dose is as effective as the two daily doses and that it improves adherence.

NTBC can be quantified in plasma and blood spots to identify the optimal required dose ${ }^{83,84}$ Dosage should be adjusted to maintain blood NTBC levels between 40 and $60 \mu \mathrm{mol} / \mathrm{L}$, which, theoretically, blocks greater than $99 \%$ of 4-HPPD activity. ${ }^{53}$ Rarely, an individual may require higher blood levels of NTBC $(70 \mu \mathrm{mol} / \mathrm{L})$ to suppress succinylacetone excretion..$^{53}$ Sander et al, reported a patient in whom a plasma NTBC concentration of $17 \mu \mathrm{mol} / \mathrm{L}$ was effective. ${ }^{84}$

NTBC should be taken on an empty stomach at least 1 hour before a meal. For children who are unable to swallow capsules, the capsules may be opened and the contents mixed in a small amount of water, formula, or apple sauce immediately before use. ${ }^{85}$

Although NTBC stops or greatly slows disease progression, any pretreatment advanced liver damage is irreversible. Therefore, patients must be closely followed for development of HCC.

NTBC is effective but very expensive. ${ }^{86}$ It is well tolerated, with few reported side effects, ${ }^{75-77}$ including transient low platelet and neutrophil counts, which may resolve without intervention and photophobia, which resolves with stricter dietary control and subsequent lowering of blood tyrosine concentrations..$^{53}$ It has been found that 4-HPPD inhibition tends to raise plasma tyrosine concentration, which may be responsible for the neurotransmitter changes recently documented by Thimm et al. ${ }^{87}$

\section{Other drug management options}

Other drug management options include carnitine supplementation and 1,25-OH-vitamin D.

Carnitine deficiency can occur secondarily to renal tubular Fanconi Syndrome, causing skeletal muscle weakness. The serum concentration of carnitine should be measured so that carnitine deficiency, if identified, can be treated..$^{88}$

Osteoporosis and rickets, resulting from renal tubular damage, are treated by the correction of acidosis, restoring calcium and phosphate balance, and the administration of 25-OH-vitamin D. ${ }^{53}$ 


\section{Dietary management}

A diet low in phenylalanine and tyrosine may result in some clinical improvement in some patients. However, the progression of the disease cannot be halted by diet alone,${ }^{73}$ with average age of survival less than ten years. ${ }^{1}$ NTCB increases blood concentration of tyrosine, necessitating a low-tyrosine diet to prevent tyrosine crystals from forming in the cornea. Dietary management should be started immediately upon diagnosis and should provide a nutritionally complete diet with controlled intakes of phenylalanine and tyrosine, using a vegetarian diet with low-protein foods and a medical formula such as Tyrex ${ }^{\circledR}$ (Ross) or Tyros ${ }^{\circledR}$ (Mead Johnson). Phenylalanine and tyrosine requirements are interdependent and vary from individual to individual and within the same individual depending on growth rate, adequacy of energy and protein intakes, and state of health. With appropriate dietary management, plasma tyrosine concentration should be maintained at 200-500 $\mu \mathrm{mol} / \mathrm{L}$, regardless of age, and plasma phenylalanine concentration should be $20-80 \mu \mathrm{mol} / \mathrm{L}$. If the blood concentration of phenylalanine is too low $(<20 \mu \mathrm{mol} / \mathrm{L})$, additional phenylalanine should be added to the diet, from milk or foods. ${ }^{53}$

\section{Liver transplantation}

Prior to the availability of NTCB, liver transplantation was the only definitive therapy for the treatment of HTT-I, but now, this should be reserved for those children who: (1) have severe liver failure at clinical presentation and fail to respond to NTCB therapy; or (2) have documented evidence of malignant changes in hepatic tissue.$^{89}$ In some countries, liver transplantation is considered in patients with good response to NTCB due to financial issues, attributed to the very high cost of NTCB. ${ }^{86}$ Whether treatment with NTCB alleviates or delays the need for liver transplantation remains to be determined. ${ }^{1}$ Although the new liver will not produce succinylacetone, the kidneys still may do; ${ }^{46}$ therefore, transplant recipients may benefit from low-dose NTCB therapy to prevent continued renal tubular and glomerular dysfunction resulting from the succinylacetone generated in renal tissue..$^{90}$

\section{Gene therapy and hepatocyte transplantation}

Although gene therapy and hepatocyte transplantation currently are not treatment options, they have received considerable publicity and are producing interesting results in mice. ${ }^{91-94}$

Gene replacement therapy is theoretically more difficult in tyrosinemia than in certain other inborn errors of metabolism because the toxic intermediates in tyrosinemia are felt to be capable of inducing HCC, and possibly kidney disease, even in the presence of normal circulating tyrosine levels; therefore, for treatment of tyrosinemia, it would not suffice to simply produce a sufficient number of cells to normalize plasma tyrosine - all hepatocytes would have to express normal FAH to avoid the risk of progression to cancer. ${ }^{23}$

Biologically, cells with a functional $F A H$ gene would have a selective advantage and might overgrow FAH-deficient cells, especially in mice. ${ }^{91-94}$

At a clinical level, it is not clear how nodules that would arise from this process could be reliably distinguished from neoplastic nodules. If major improvements occur in gene transfer technology, in vivo cell selection, and the detection of hepatocellular carcinoma, they could have an important impact on the feasibility of gene therapy or hepatocyte transplantation in tyrosinemia. ${ }^{23}$

\section{Genetic counseling}

As with all genetic diseases, genetic counseling is appropriate to help families understand the recurrence risks and ensure that they receive proper evaluation and care. ${ }^{13}$

\section{Cognitive evaluation}

Cognitive evaluation, ${ }^{77}$ by a developmental psychologist, should be done close to school age and then at around age 10 , to see how the patient is intellectually developing. About $35 \%$ of patients with HTT-I appear to have significant learning difficulties; the etiology of these cognitive defects is uncertain. ${ }^{46}$ Patients with tyrosinemia who are treated appropriately will have the same intellectual potential as their siblings without tyrosinemia. ${ }^{46}$

\section{Monitoring of combined dietary and NTCB management}

With adequate treatment, complete blood count indices, liver and kidney function tests normalize, $\alpha$-fetoprotein levels drop rapidly until normalized, and succinylacetone disappears from the blood $(<0.1 \mu \mathrm{mol} / \mathrm{L})$ and urine $(<1 \mu \mathrm{mol} / \mathrm{mol}$ creatinine).$^{46}$ Delta-aminolevulinic acid urine levels should be between $0-3 \mu \mathrm{mol} / \mathrm{mol}$ creatinine. ${ }^{20}$

Tyrosine, phenylalanine and methionine should be measured to ensure that dietary management is appropriate for the patient's weight and size. Blood tyrosine levels should be maintained between 200 and $500 \mu \mathrm{mol} / \mathrm{L}$, as higher levels can lead to tyrosine crystals in the eyes. Blood phenylalanine levels should be between 35 and $120 \mu \mathrm{mol} / \mathrm{L} .{ }^{46}$

NTCB blood levels should be maintained between 30-60 $\mu \mathrm{mol} / \mathrm{L}$. These should be done in the first six months following initiation of treatment, then every three to six months thereafter. ${ }^{46,53}$ Abdominal ultrasonography 
should be done every six months forever and abdominal computerized tomography scan or magnetic resonance imaging annually. ${ }^{46}$

\section{HTT-II}

In HTT-II, a diet low in tyrosine and phenylalanine corrects the chemical abnormalities and results in dramatic healing of the skin and eye lesions. ${ }^{45}$ It is necessary to achieve a total intake of phenylalanine and tyrosine $<100 \mathrm{mg} / \mathrm{kg}$ /day to obtain plasma concentrations of tyrosine $<10 \mathrm{mg} / \mathrm{dL} .{ }^{95}$

Patients respond to vitamin A supplementation with clearing of the skin lesions, and they should also be given a trial of pyridoxine phosphate. Mental retardation may be prevented by early dietary restriction of tyrosine. ${ }^{13}$

\section{HTT-III}

A diet low in tyrosine and phenylalanine in combination with vitamin $\mathrm{C}$ supplementation causes a dramatic decrease in plasma tyrosine levels. ${ }^{13,45}$

\section{Transient tyrosinemia of the newborn}

Here, hypertyrosinemia usually resolves spontaneously during the first month of life. It is often corrected promptly by reducing the amount of protein in the diet to $2 \mathrm{~g} / \mathrm{kg} / 24 \mathrm{hr}$ and the infant usually does well on breast milk. Normalization of tyrosine level is hastened by vitamin $\mathrm{C}$ supplementation $(200-400 \mathrm{mg} / 24 \mathrm{hr}) .^{1,13}$

\section{Disclosure}

The authors report no conflicts of interest in this work.

\section{References}

1. Mitchell GA, Rezvani I. Defects in metabolism of amino acids. Tyrosine. In: Kliegman RM, Stanton BF, St Geme JW, Schor NF, Behrman RE, editors. Nelson Textbook of Pediatrics, 19th ed. Philadelphia: Saunders Elsevier; 2011:422-405.

2. omim.org [homepage on the Internet]. Tyrosinemia type 1. Online Mendelian Inheritence in Man (OMIM); 1986 [updated October 12, 2005]. Available from: http://omim.org/entry/276700. Accessed November 24, 2012.

3. Stenson PD, Ball EV, Mort M, et al. Human Gene Mutation Database (HGMD): 2003 update. Hum Mutat. 2003;21(6):577-581.

4. Couce ML, Dalmau J, del Toro M, Pintos-Morell G, Aldámiz-Echevarría L; for the Spanish Working Group on Tyrosinemia Type 1. Tyrosinemia type 1 in Spain: mutational analysis, treatment and long-term outcome. Pediatr Int. 2011;53(6):985-989.

5. Medes G. A new error of tyrosine metabolism: tyrosinosis. The intermediary metabolism of tyrosine and phenylalanine. Biochem J. 1932;26(4):917-940.

6. Baber MD. A case of congenital cirrhosis of the liver with renal tubular defects akin to those in the Fanconi syndrome. Arch Dis Child. 1956; 31(159):335-339.

7. Sakai K, Kitagawa T. An atypical case of tyrosinosis (1-parahydroxyphenyllactic aciduria). Part 1 . Clinical and laboratory findings. Jikei Med J. 1957;2:1-10.
8. Sakai K, Kitagawa T. An atypical case of tyrosinosis (1-parahydroxyphenyllactic aciduria). Part 2. A research on the metabolic block. Jikei Med J. 1957;2:11-15.

9. Sakai K, Kitagawa T, Yoshioka K. An atypical case of tyrosinosis (1-parahydroxyphenyllactic aciduria). Part 3. The outcome of the patient; pathological and biochemical observations of the organ tissues. Jikei Med J. 1959;6:15-24.

10. Larochelle J, Privé L, Bélanger M, et al. Hereditary tyrosinemia. I. Clinical and biological study of 62 cases. Pediatrie. 1973;28(1):5-18. French.

11. Paradis K, Weber A, Seidman EG, et al. Liver transplantation for hereditary tyrosinemia: the Quebec experience. Am J Hum Genet. 1990;47(2):338-342.

12. Kvittingen EA. Hereditary tyrosinemia type I-an overview. Scand $J$ Clin Lab Invest Suppl. 1986;184:S27-S34.

13. perkinelmergenetics.com [homepage on the Internet]. Tyrosinemia. PerkinElmer Genetics; 2008. Available from: http://www.perkinelmergenetics. com/Tyrosinemia.htm. Accessed November 23, 2012.

14. Nyhan WL. Abnormalities in Amino Acid Metabolism in Clinical Medicine. Norwalk: Appleton-Century-Crofts; 1984.

15. Cerone R, Holme E, Schiaffino MC, Caruso U, Maritano L, Romano C. Tyrosinemia type III: diagnosis and ten-year follow-up. Acta Pediatr. 1997;86(9):1013-1015.

16. Heylen E, Scherer G, Vincent MF, Marie S, Fischer J, Nassogne MC. Tyrosinemia Type III detected via neonatal screening: management and outcome. Mol Genet Metab. 2012;107(3):605-607.

17. Jonas MM, Perez-Atayde AR. Liver disease in infancy and childhood. In: Schiff ER, Sorrell MF, Maddrey WC, editors. Schiff's Diseases of the Liver, 10th ed. Philadelphia: Lippincott Williams \& Wilkins; 2007:1307-1347.

18. El-Shabrawi MH, Kamal NM. Medical management of chronic liver diseases in children (part I): focus on curable or potentially curable diseases. Paediatr Drugs. 2011;13(6):357-370.

19. Schlune A, Thimm E, Herebian D, Spiekerkoetter U. Single dose NTBC-treatment of hereditary tyrosinemia type I. J Inherit Metab Dis. 2012;35(5):831-836.

20. Ashorn M, Pitkänen S, Salo MK, Heikinheimo M. Current strategies for the treatment of hereditary tyrosinemia type I. Paediatr Drugs. 2006;8(1):47-54.

21. Russo PA, Mitchell GA, Tanguay RM. Tyrosinemia: a review. Pediatr Dev Pathol. 2001;4(3):212-221.

22. Sherlock S, Dooley J. Nutritional and metabolic liver diseases. In: Sherlock S, Dooley J, editors. Diseases of the Liver and Biliary System, 11th ed. Oxford: Blackwell Science; 2002:423-452.

23. Mitchell G, Russo PA, Dubois J, Alvarez F. Tyrosinemia. In: Suchy FJ, Sokol RJ, Balistreri WF, editors. Liver Disease in Children, 3rd ed. New York: Cambridge University Press; 2007:694-713.

24. Weinberg AG, Mize CE, Worthen HG. The occurrence of hepatoma in the chronic form of hereditary tyrosinemia. J Pediatr. 1976; 88(3):434-438.

25. Sassa S, Kappas A. Hereditary tyrosinemia and the heme biosynthesic pathway. Profound inhibition of delta-aminolevulinic acid dehydratase activity by succinylacetone. $J$ Clin Invest. 1983;73(3):625-634.

26. Tschudy DP, Hess RA, Frykholm BC. Inhibition of delta-aminolevulinic acid dehydrase by 4,6-dioxohepatanoic acid. J Biol Chem. 1981; 256(19):9915-9923.

27. Sassa S, Fujita H, Kappas A. Succinylacetone and delta-aminolevulinic acid dehydratase in hereditary tyrosinemia: immunochemical study of the enzyme. Pediatrics. 1990;86(1):84-86.

28. Mitchell G, Larochelle J, Lambert M, et al. Neurologic crises in hereditary tyrosinemia. N Engl J Med. 1990;322(7):432-437.

29. Rank JM, Pascual-Leone A, Payne W, et al. Hematin therapy for the neurologic crisis of tyrosinemia. J Pediatr. 1991;118(1): $136-139$.

30. Kappas A, Sassa S, Galbraith R. The porphyrias. In: Scriver CR, Beaudet AL, Sly WS, Valle D, editors. The Metabolic Basis of Inherited Disease, 6th ed. New York: McGraw-Hill. 1989:1305-1366. 
31. Kvittingen EA, Talseth T, Halvorsen S, Jakobs C, Hovig T, Flatmark A. Renal failure in adult patients with hereditary tyrosinaemia type I. J Inherit Metab Dis. 1991;14(1):53-62.

32. Privé L. Pathological findings in patients with tyrosinemia. Can Med Assoc J. 1967;97(18):1054-1056.

33. Kvittingen EA, Brodtkorb E. The pre- and post-natal diagnosis of tyrosinemia type I and the detection of the carrier state by assay of fumarylacetoacetase. Scand J Clin Lab Invest Suppl. 1986;184:S35-S40.

34. Bendon RW, Hug G. Glycogen accumulation in the pars recta of the proximal tubule in Fanconi syndrome. Pediatr Pathol. 1986;6(4): 411-429.

35. Lindblad B, Fällström SP, Höyer S, Nordborg C, Solymar L, Velander H. Cardiomyopathy in fumarylacetoacetase deficiency (hereditary tyrosinaemia): a new feature of the disease. J Inherit Metab Dis. 1987; 10(Suppl 2):S319-S322.

36. André N, Roquelaure B, Jubin V, Ovaert C. Successful treatment of severe cardiomyopathy with NTBC in a child with tyrosinaemia type I. J Inherit Metab Dis. 2005;28:103-106.

37. Arora N, Stumper O, Wright J, Kelly DA, McKiernan. Cardiomyopathy in tyrosinaemia type I is common but usually benign. J Inherit Metab Dis. 2006;29(1):54-57.

38. Edwards MA, Green A, Colli A, Rylance G. Tyrosinaemia type I and hypertrophic obstructive cardiomyopathy. Lancet. 1987; 1(8547):1437-1438.

39. Halvorsen S, Pande H, Loken AC, Giessing LR. Tyrosinosis. A study of 6 cases. Arch Dis Child. 1966;41(217):238-249.

40. Perry TL. Tyrosinemia associated with hypermethioninemia and islet cell hyperplasia. Can Med Assoc J. 1967;97(18):1067-1075.

41. Jetvic MM, Thorp FK, Hruban Z. Hereditary tyrosinemia with hyperplasia of juxtaglomerular apparatus. Am J Clin Pathol. 1974; 61(3):423-437.

42. Baumann U, Preece MA, Green A, Kelly DA, McKiernan PJ. Hyperinsulinism in tyrosinaemia type I. J Inherit Metab Dis. 2005; 28(2):131-135.

43. Macsai MS, Schwartz TL, Hinkle D, Hummel MB, Mulhern MG, Rootman D. Tyrosinemia type II: nine cases of ocular signs and symptoms. Am J Ophthalmol. 2001;132(4):522-527.

44. Mitchell GA, Grompe M, Lambert M, Tanguay RM. Hypertyrosinemia. In: Scriver CR, Beaudet AL, Sly WS, Valle D, editors. The Metabolic and Molecular Bases of Inherited Disease, 8th ed. New York: McGraw Hill; 2001:1777-1806.

45. Ellaway CJ, Holme E, Standing S, et al. Outcome of tyrosinaemia type III. J Inherit Metab Dis. 2001;24(8):824-832.

46. Couce ML, Aldámiz-Echevarría L, Baldellou A, et al. Recommendations and management of type I hereditary or hepatorenal tyrosinemia. $A n$ Pediatr (Barc). 2010;73(5):279. Spanish.

47. University of Washington. Biochemical Genetics Clinic [homepage on the Internet]. Seattle: The University of Washington Biochemical Genetics Clinic; updated 2004. Available from: http://depts.washington. edu/tyros/hcp.htm. Accessed January 13, 2013.

48. Grenier A, Lescault A, Laberge C, Gagné R, Marmer O. Detection of succinylacetone and the use of its measurement in mass screening for hereditary tyrosinemia. Clin Chim Acta. 1982;123(1-2):93-99.

49. Magera MJ, Gunawardena ND, Hahn SH, et al. Quantitative determination of succinylacetone in dried blood spots for newborn screening of tyrosinemia type I. Mol Genet Metab. 2006;88(1):16-21.

50. Allard P, Grenier A, Korson MS, Zytkovicz TH. Newborn screening for hepatorenal tyrosinemia by tandem mass spectrometry: analysis of succinylacetone extracted from dried blood spots. Clin Biochem. 2004;37(11):1010-1015.

51. Al-Dirbashi OY, Rashed MS, Jacob M, et al. Improved method to determine succinylacetone in dried blood spots for diagnosis of tyrosinemia type 1 using UPLC-MS/MS. Biomed Chromatogr. 2008;22(11):1181-1185.

52. Dubois J, Garel L, Patriquin H, et al. Imaging features of type 1 hereditary tyrosinemia: a review of 30 patients. Pediatr Radiol. 1996;26(12):845-851.
53. Sniderman King L, Trahms C, Scott CR. Tyrosinemia type 1. In: Pagon RA, Bird TC, Dolan CR, Stephens K, Adam MP, editors. Gene Reviews. Seattle: University of Washington; 2006 [updated August 25, 2011]. Available from: http://www.ncbi.nlm.nih.gov/books/NBK1515/. Accessed January 13, 2013.

54. Laberge C, Grenier A, Valet JP, Morissette J. Fumarylacetoacetase measurement as a mass-screening procedure for hereditary tyrosinemia type I. Am J Hum Genet. 1990;47(2):325-328.

55. Jakobs C, Stellaard F, Kvittingen EA, Henderson M, Lilford R. Firsttrimester prenatal diagnosis of tyrosinemia type I by amniotic fluid succinylacetone determination. Prenat Diagn. 1990;10(2):133-134.

56. Grompe M, St-Louis M, Demers SI, al-Dhalimy M, Leclerc B, Tanguay RM. A single mutation of the fumarylacetoacetate hydrolase gene in French Canadians with hereditary tyrosinemia type I. $N$ Engl J Med. 1994;331(6):353-357.

57. Poudrier J, St-Louis M, Lettre F, et al. Frequency of the IVS12 + 5G A splice mutation of the fumarylacetoacetate hydrolase gene in carriers of hereditary tyrosinaemia in the French-Canadian population of Saguenay-Lac-St-Jean. Prenat Diagn. 1996;16(1):59-64.

58. Ploos van Amstel JK, Bergman AJ, van Beurden EA, et al. Hereditary tyrosinemia type 1: novel missense, nonsense and splice consensus mutations in the human fumarylacetoacetate hydrolase gene; variability of the genotype-phenotype relationship. Hum Genet. 1996; 97(1):51-59.

59. St-Louis M, Leclerc B, Laine J, Salo MK, Holmberg C, Tanguay RM. Identification of a stop mutation in five Finnish patients suffering from hereditary tyrosinemia type I. Hum Mol Genet. 1994;3(1):69-72.

60. Rootwelt H, Høie K, Berger R, Kvittingen EA. Fumarylacetoacetate mutations in tyrosinaemia type I. Hum Mutat. 1996;7(3):239-243.

61. Rootwelt H, Berger R, Gray G, Kelly DA, Coskun T, Kvittingen EA. Novel splice, missense, and nonsense mutations in the fumarylacetoacetase gene causing tyrosinemia type 1. Am J Hum Genet. 1994;55(4):653-658

62. Kvittingen EA, Børresen AL, Stokke O, van der Hagen CB, Lie SO. Deficiency of fumarylacetoacetase without hereditary tyrosinemia. Clin Genet. 1985;27(6):550-554.

63. Sander J, Janzen N, Peter M, et al. Newborn screening for hepatorenal tyrosinemia: Tandem mass spectrometric quantification of succinylacetone. Clin Chem. 2006;52(3):482-487.

64. la Marca G, Malvagia S, Pasquini E, et al. The inclusion of succinylacetone as marker for tyrosinemia type I in expanded newborn screening programs. Rapid Commun Mass Spectrom. 2008;22(6):812-818.

65. Al-Dirbashi OY, Rashed MS, Brink HJ, et al. Determination of succinylacetone in dried blood spots and liquid urine as a dansylhydrazone by liquid chromatography tandem mass spectrometry. J Chromatogr $B$ Analyt Technol Biomed Life Sci. 2006;831(1-2):274-280.

66. Mieles LA, Esquivel CO, Van Thiel DH, et al. Liver transplantation for tyrosinemia. A review of 10 cases from the University of Pittsburgh. Dig Dis Sci. 1990;35(1):153-157.

67. Van Thiel DH, Gartner LM, Thorp FK, et al. Resolution of the clinical features of tyrosinemia following orthotopic liver transplantation for hepatoma. J Hepatol. 1986;3(1):42-48.

68. van Spronsen FJ, Berger R, Smit GP, et al. Tyrosinaemia type I: orthotopic liver transplantation as the only definitive answer to a metabolic as well as an oncological problem. J Inherit Metab Dis. 1989; 12 Suppl 2:S339-S342.

69. Pitkänen ST, Salo MK, Heikinheimo M. Hereditary tyrosinaemia type I: from basics to progress in treatment. Ann Med. 2000;32(8):530-538.

70. Lindstedt S, Holme E, Lock EA, Hjalmarson O, Strandvik B. Treatment of hereditary tyrosinaemia type I by inhibition of 4-hydroxyphenylpyruvate dioxygenase. Lancet. 1992;340(8823):813-817.

71. Lock EA, Ellis MK, Gaskin P, et al. From toxicological problem to therapeutic use: the discovery of the mode of action of 2-(2-nitro4-trifluoromethylbenzoyl)-1,3-cyclohexanedione (NTBC), its toxicology and development as a drug. J Inherit Metab Dis. 1998; 21(5):498-506. 
72. Schwetz BA. From the Food and Drug Administration. JAMA. 2002; 287(9):1103.

73. Holme E, Lindstedt S. Diagnosis and management of tyrosinemia type 1. Curr Opin Pediatr. 1995;7:726-732.

74. Holme E, Lindstedt S. Tyrosinaemia type1 and NTBC (2-(2-nitro-4trifluoromethylbenzoyl)-1,3-cyclohexanedione). J Inherit Metab Dis. 1998;21(5):507-517.

75. Holme E, Lindstedt S. Nontransplant treatment of tyrosinemia. Clin Liver Dis. 2000;4:805-814.

76. Joshi SN, Venugopalan P. Experience with NTBC therapy in hereditary tyrosinaemia type 1: an alternative to liver transplantation. Anal Trop Paediatr. 2004;24(3):259-265.

77. Masurel-Paulet A, Poggi-Bach J, Rolland MO, et al. NTBC treatment in tyrosinaemia type I: long-term outcome in French patients. $J$ Inherit Metab Dis. 2008;31(1):81-87.

78. Larochelle J, Alvarez F, Bussières JF, et al. Effect of nitisinone (NTBC) treatment on the clinical course of hepatorenal tyrosinemia in Québec. Mol Genet Metab. 2012;107(1-2):49-54.

79. Holme E. Disorders of tyrosine degradation. In: Blau N, Leonard J, Hoffmann GF, Clarke JTR, editors. Physicians Guide to the Treatment and Follow-Up of Metabolic Diseases. Berlin: Springer; 2006:49-55.

80. El-Karaksy H, Rashed M, El-Sayed R, et al. Clinical practice. NTBC therapy for tyrosinemia type 1: how much is enough? Eur $J$ Pediatr. 2010;169(6):689-693.

81. D’Eufemia P, Celli M, Tetti M, Finocchiaro R. Tyrosinemia type I: long-term outcome in a patient treated with doses of NTBC lower than recommended. Eur J Pediatr. 2011;170(6):819.

82. Hall MG, Wilks MF, Provan W, Eksborg S, Lumholtz B. Pharmacokinetics and pharmacodynamics of NTBC (2-(2-nitro-4-fluoromethylbenzoyl)1,3-cyclohexanedione) and mesotrione, inhibitors of 4-hydroxyphenyl pyruvate dioxygenase (HPPD) following a single dose to healthy male volunteers. Br J Clin Pharmacol. 2001;52(2):169-177.

83. Herebian D, Spiekerkötter U, Lamshöft M, Thimm E, Laryea M, Mayatepek E. Liquid chromatography tandem mass spectrometry method for the quantitation of NTBC (2-(nitro-4-trifluoromethy lbenzoyl)1,3-cyclohexanedione) in plasma of tyrosinemia type 1 patients. J Chromatogr B Analyt Technol Biomed Life Sci. 2009;877(14-15):1453-1459.
84. Sander J, Janzen N, Terhardt M, et al. Monitoring tyrosinaemia type I: Blood spot test for nitisinone (NTBC). Clin Chim Acta. 2011;412(1-2):134-138.

85. webmd.com [homepage on the Internet]. Drugs and medications nitisinone oral. WebMD; 2005-2013. Available from: http://www. webmd.com/drugs/drug-32531-nitisinone+Oral.aspx?drugid=32531\&d rugname $=$ nitisinone + Oral\&source $=2$. Accessed November 25, 2012.

86. El-Karaksy H, Fahmy M, El-Raziky M, et al. Hereditary tyrosinemia type 1 from a single center in Egypt: clinical study of 22 cases. World J Pediatr. 2011;7(3):224-231.

87. Thimm E, Herebian D, Assmann B, Klee D, Mayatepek E, Spiekerkoetter U. Increase of CSF tyrosine and impaired serotonin turnover in tyrosinemia type I. Mol Genet Metab. 2011;102(2):122-125.

88. Nissenkorn A, Korman SH, Vardi O, et al. Carnitine-deficient myopathy as a presentation of tyrosinemia type I. J Child Neurol. 2001; 16(9):642-624.

89. Mohan N, McKiernan P, Preece MA, et al. Indications and outcome of liver transplantation in tyrosinaemia type 1. Eur J Pediatr. 1999; 158 Suppl 2:S49-S54.

90. Pierik LJ, van Spronsen FJ, Bijleveld CM, van Dael CM. Renal function in tyrosinaemia type I after liver transplantation: a long-term follow-up. J Inherit Metab Dis. 2005;28(6):871-876.

91. Overturf K, al-DhalimyM, Ou CN, Finegold M, Grompe M. Serial transplantation reveals the stem-cell-like regenerative potential of adult mouse hepatocytes. Am J Pathol. 1997;151(5):1273-1280.

92. Grompe M. Therapeutic liver repopulation for the treatment of metabolic liver diseases. Hum Cell. 1999;12(4):171-180.

93. Lee LA. Advances in hepatocyte transplantation: a myth becomes reality. J Clin Invest. 2001;108(3):367-369.

94. Wang X, Foster M, A1 Dhalimy M, Lagasse E, Finegold M, Grompe M. The origin and liver repopulating capacity of murine oval cells. Proc Natl Acad Sci U SA. 2003;100 Suppl 1:S11881-S11888.

95. Ney D, Bay C, Schneider JA, Kelts D, Nyhan WL. Dietary management of oculocutaneous tyrosinemia in an 11-year-old child. Am J Dis Child. 1983;137(10):995-1000.

96. Kitagawa T. Hepatorenal tyrosinemia. Proc Jpn Acad Ser B Phys Biol Sci. 2012;88(5):192-200.
Orphan Drugs: Research and Reviews

\section{Publish your work in this journal}

Orphan Drugs: Research and Reviews is an international, peer-reviewed, open access journal publishing original research, reports, reviews and commentaries on all areas of the design and development of orphan drugs for the treatment of rare diseases through to clinical applications. Clinical outcomes, patient safety, and programs for the development and

\section{Dovepress}

effective, safe, and sustained use of medicines will be a feature of the journal. The manuscript management system is completely online and includes a very quick and fair peer-review system, which is all easy to use. Visit http://www.dovepress.com/testimonials.php to read real quotes from published authors. 